\title{
FACTORS ASSOCIATED WITH FOOD NEOPHOBIA IN CHILDREN: SYSTEMATIC REVIEW
} Fatores associados à neofobia alimentar em crianças: revisão sistemática

\author{
Thamara de Oliveira Torres ${ }^{a}$ (D), Daiene Rosa Gomes ${ }^{a, *}$ (i), Mússio Pirajá Mattos ${ }^{a}$ (i)
}

\section{ABSTRACT}

Objective: To identify the factors associated with food neophobia in children through a systematic review.

Data sources: This research was based on the recommendations of the Preferred Reporting Items for Systematic Reviews and MetaAnalyses. The research was carried out in the PubMed, Science Direct, and Scientific Electronic Library Online databases, with the combination of health descriptors in English and Portuguese: ("Food Neophobia" OR "Feeding Behavior" OR "Food Preferences" OR "Food Selectivity") AND Child, from 2000 to 2019. Studies that evaluated factors associated with food neophobia in children were included. The quality of the studies was assessed using the Effective Public Health Practice Project: Quality Assessment Tool for Quantitative Studies (QATQS).

Data synthesis: 19 studies were included in the systematic review. The prevalence of food neophobia ranged from 12.8 to $100 \%$. The studies used three different scales to measure the level of food neophobia. The main factors associated with food neophobia were: parental influence on children's eating habits, children's innate preference for sweet and savory flavors, influence of the sensory aspect of the food, parents' pressure for the child to eat, parents' lack of encouragement and/or affection at mealtime, childhood anxiety, and diets with low variety and low nutritional quality.

Conclusions: The factors associated with food neophobia permeate several areas of the child's life, thus, interprofessional follow-up becomes essential in the intervention process.

Keywords: Food neophobia; Feeding behavior; Food preferences; Children; Systematic review.

\section{RESUMO}

Objetivo: Identificar os fatores associados à neofobia alimentar em crianças por meio de uma revisão sistemática.

Fontes de dados: Esta pesquisa foi baseada nas recomendações do Preferred Reporting Items for Systematic Reviews and MetaAnalyses. A busca foi realizada nas bases de dados PubMed, ScienceDirect e Scientific Electronic Library Online (SciELO), com a conjugação dos descritores em saúde em português e inglês: ("Food Neophobia" OR "Feeding Behavior" OR "Food Preferences" OR "Food Selectivity") AND Child, no período de 2000 a 2019. Foram incluídos os estudos que avaliaram os fatores associados à neofobia alimentar em crianças. A qualidade dos estudos foi mensurada por meio da ferramenta Effective Public Health Practice Project: Quality Assessment Tool for Quantitative Studies (QATQS).

Síntese dos dados: Dezenove trabalhos foram incluídos na revisão sistemática. A prevalência da neofobia alimentar variou de 12,8 a $100 \%$. Os estudos utilizaram três diferentes escalas a fim de medir o nível de neofobia alimentar. Os principais fatores associados a esse quadro foram: influência parental nos hábitos alimentares da criança, preferência inata das crianças por sabores doces e salgados, influência do aspecto sensorial do alimento, pressão dos pais para a criança comer, falta de encorajamento e/ ou afetividade dos pais no momento das refeições, ansiedade na infância, dietas pouco variadas e com baixa qualidade nutricional. Conclusões: Os fatores associados à neofobia alimentar permeiam diversos âmbitos da vida da criança, assim, o acompanhamento interprofissional torna-se essencial no processo de intervenção. Palavras-chave: Neofobia alimentar; Comportamento alimentar; Preferências alimentares; Crianças; Revisão sistemática. 


\section{INTRODUCTION}

Food neophobia is characterized by a reluctance to consume or an unwillingness to try unknown foods. ${ }^{1}$ This behavior, from an evolutionary perspective, can minimize risks of eating foods harmful to health; however, this aversion causes food monotony, which can result in nutritional deficiencies. ${ }^{2,3}$ Food should not be solely seen as a basic need, but also as a source of pleasure, socialization, cultural transmission, and a factor of great importance for health. ${ }^{4}$ These aspects influence the formation of eating habits, which mostly originate in childhood, and the family has a paramount role in learning how to feed the child. ${ }^{5}$

The neophobic behavior mainly occurs in the age group of two to five years, a significant period for the formation of eating habits. ${ }^{6}$ Due to the limited knowledge of this behavior, many parents do not identify it in their children, which reinforces the possibility that the prevalence of neophobia is even greater than the data reported in the literature. ${ }^{5}$ The lack of identification of neophobia is worrisome, considering that the foods that most drive it are of high nutritional value. ${ }^{7}$

The development of food neophobia is associated with several factors such as individual, biological, psychological, economic, anthropological, and sociocultural factors. ${ }^{8}$ Knowledge of such elements allows developing an adequate approach to face neophobia, considering that eating behavior may be differently influenced. For intervention to take place, it is essential to study this condition associated with other variables, especially the eating habits of those who most strongly influence the children's food preferences.

The lack of diversity in food caused by food neophobia restricts the intake of nutrients necessary to maintain the body homeostasis. When this restriction is severe and/or lasts for a long time, it tends to affect various systems of the human body, such as the nervous system, affecting the child's cognitive and motor abilities. ${ }^{10}$

Considering the factors associated with food neophobia in children and its impact on their development, it is necessary to carry out studies on this issue in order to enable the dissemination of knowledge of neophobia and, consequently, its prevention, early identification, and appropriate intervention. It is worth considering that the difficult identification of neophobia causes this behavior to last long enough to severely affect the child's development and health. Therefore, the present study aims to identify factors associated with food neophobia in children through a systematic review.

\section{METHOD}

This is a systematic review study, based on the standards of the Preferred Reporting Items for Systematic Reviews and MetaAnalyses (PRISMA), ${ }^{11}$ on studies that evaluated the factors associated with food neophobia in children. In this review, the concept of food neophobia was adopted as the tendency to reject new or unknown foods. ${ }^{1}$ However, due to the conceptual confusion still present in the literature, there was need to include other descriptors in the search for articles.

To do so, an electronic investigation of articles indexed in the PubMed, ScienceDirect, and Scientific Electronic Library Online (SciELO) databases was carried out, with the combination of the following descriptors in English and Portuguese languages (DeSC/MeSH): ("Food Neophobia" OR "Feeding Behavior" OR "Food Preferences" OR "Food Selectivity") AND Child and ("Neofobia Alimentar" OR "Comportamento Alimentar" OR "Preferências Alimentares" OR "Seletividade Alimentar") AND Criança. Studies published from January 2000 to December 2019 were considered.

Articles that analyzed factors associated with food neophobia in children, published in Portuguese and in English, were included. Reviews, theses, dissertations, editorials, and studies that did not correlate with the used descriptors were excluded. Studies available from the databases were selected and analyzed by two independent reviewers (TOT and DRG), using forms that comprised the eligibility criteria, including the title, the abstract and, finally, the full article. Disagreements between the two reviewers were resolved in consultation with a third reviewer (MPM).

Relevant information of the selected articles was systematized in a Word spreadsheet containing the following data: authors, year of publication, study locations, study types, sample, quality score, prevalence of food neophobia in children, food neophobia scale, level of neophobia, source environment of the sample, and associated factors. The study location was described according to the country and city of performance. As for the temporal aspect, articles were presented according to the year of publication. The sample of each study was characterized by the number of participants.

The methodological quality of the selected articles was assessed by using the scale Effective Public Health Practice Project: Quality Assessment Tool for Quantitative Studies (QATQS) (https://merst. ca/wp-content/uploads/2018/02/quality-assessment-tool_2010. pdf). With this tool, publications were analyzed according to five components (classified as strong, moderate, or weak): selection bias, study design, confounders, data collection method, and type of analysis employed. Subsequently, the studies were classified as follows: (1) strong, for studies that did not present components classified as weak; (2) moderate, for studies that presented only one weak component; (3) weak, for studies that presented two or more components with the same classification.

\section{RESULTS}

The search strategies are shown in Figure 1. A total of 8,542 articles were identified in the databases. The excluded studies consisted in review articles, theses, dissertations, and editorials, 
in addition to duplicates; those that did not address food neophobia in childhood were also excluded. Thus, 19 articles were selected for analysis in the systematic review. ${ }^{2,12-29}$

The main characteristics of the selected studies are presented in Table 1. When classifying them according to type of study, the exclusive presence of cross-sectional research was noteworthy. The selected studies were carried out in 10 different countries, with the United States of America consisting in the country with the most publications (five articles), ${ }^{2,12-15}$ followed by Australia (four articles). ${ }^{11,16-18}$ The selected studies were conducted in the years $2000,{ }^{2} 2003,{ }^{12}$ $2006,{ }^{19} 2008,{ }^{16} 2010,{ }^{20} 2012,{ }^{14,17} 2014,{ }^{21,22} 2015,{ }^{18,23} 2016,{ }^{13,24}$ $2017,{ }^{15,25,26} 2018^{27,28}$ and $2019 .{ }^{29}{ }^{29}$ Concerning the language, the 19 articles were written in English. The sample size of the studies ranged from 70 to 560 children of diverse origin in criteria such as: school environment, ${ }^{2,15,16,19,20,22,23,25-29}$ home environment, ${ }^{12-14}$ hospital environment, ${ }^{24}$ and pediatric outpatient clinic. ${ }^{17,18,21}$

In the evaluation of methodological rigor, according to the QATQS criteria, 14 (74\%) articles were classified as moderate $^{13-19,20-24,27-29}$ and 5 (26\%), as weak..$^{2,12,23,25,26}$ The study design was the item that contributed to moderately classify the quality of the study; on the other hand, precision in data collection and confounders were the items that most contributed to the weak methodological rigor (Figure 2).

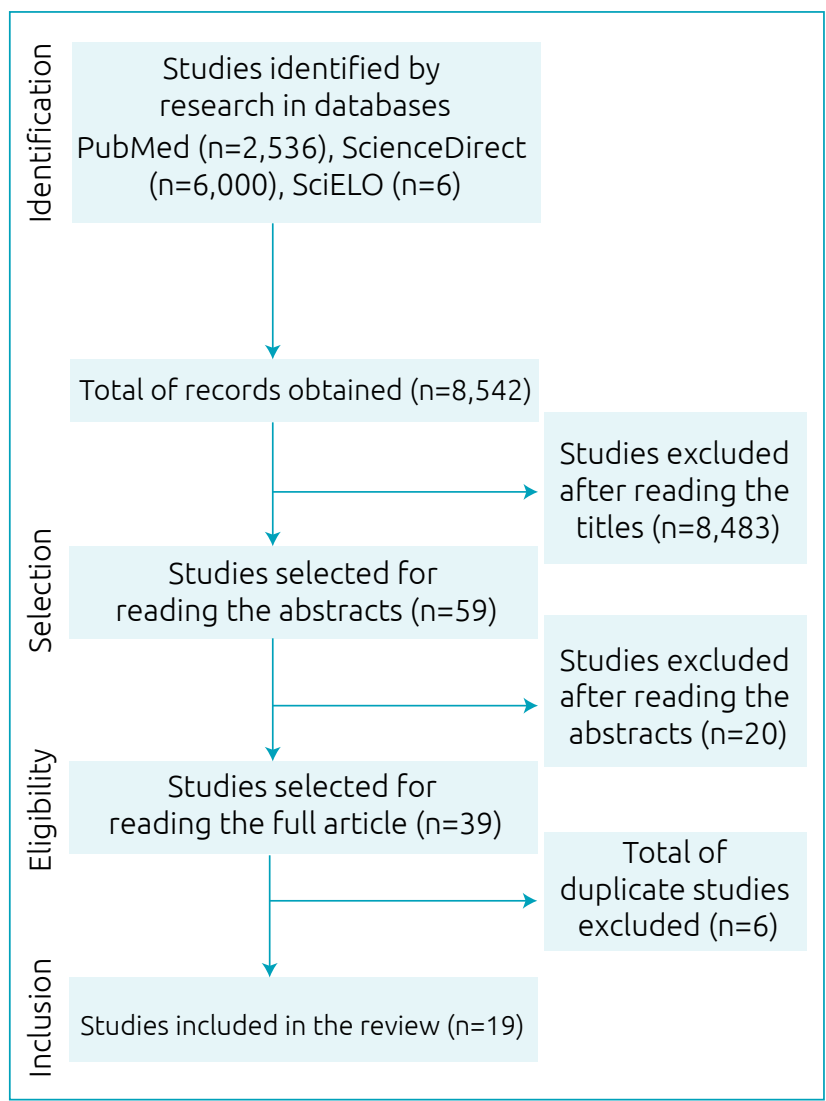

Figure 1 Flowchart of the search strategy and results from the databases.

Table 1 Characteristics of the studies selected in the systematic review of food neophobia in children.

\begin{tabular}{|c|c|c|c|}
\hline Author/year & Study location/type & Sample & Quality score \\
\hline Falciglia et al. $(2000)^{2}$ & $\begin{array}{l}\text { United States of America- } \\
\text { Cincinnati/Cross-sectional }\end{array}$ & 70 children & Weak \\
\hline Galloway et al. (2003) ${ }^{12}$ & $\begin{array}{l}\text { United States of America - } \\
\text { Pennsylvania/Cross-sectional }\end{array}$ & 192 children (7 years) & Weak \\
\hline Cooke et al. (2006) & $\begin{array}{l}\text { United Kingdom - } \\
\text { London/Cross-sectional }\end{array}$ & $\begin{array}{c}109 \text { children } \\
\text { (average age of } 9 \text { years) }\end{array}$ & Moderate \\
\hline Russell and Worsley $(2008)^{16}$ & Australia - Burwood/Cross-sectional & 371 children (2 to 5 years) & Moderate \\
\hline Mustonen and Tuorila (2010) ${ }^{20}$ & Finland - Helsinki/Cross-sectional & 164 children (8 to 11 years) & Moderate \\
\hline Howard et al. (2012) ${ }^{17}$ & $\begin{array}{c}\text { Australia - Brisbane and Adelaide/ } \\
\text { Cross-sectional }\end{array}$ & 277 children & Moderate \\
\hline Tan and Holub (2012) ${ }^{14}$ & $\begin{array}{c}\text { United States of America - } \\
\text { Dallas/Cross-sectional }\end{array}$ & 85 children (3 to 12 years) & Moderate \\
\hline Cassells et al. $(2014)^{21}$ & Australia - Adelaide/Cross-sectional & 244 children & Moderate \\
\hline Laureati et al. $(2014)^{22}$ & Italy - Milan/Cross-sectional & 560 children & Moderate \\
\hline Maratos and Staples $(2015)^{23}$ & England - Derby/Cross-sectional & 70 children (8 to 11 years) & Weak \\
\hline Perry et al. $(2015)^{18}$ & Australia - Brisbane/Cross-sectional & 330 children (2 years) & Moderate \\
\hline Kaar et al. $(2016)^{13}$ & $\begin{array}{c}\text { United States of America - } \\
\text { Aurora/Cross-sectional }\end{array}$ & 210 children (3 to 5 years) & Moderate \\
\hline Moding and Stifter $(2016)^{24}$ & $\begin{array}{l}\text { United States of America - } \\
\text { Pennsylvania/Cross-sectional }\end{array}$ & 115 children & Moderate \\
\hline Kozioł-Kozakowska et al. (2018) ${ }^{25}$ & Poland - Krakow/Cross-sectional & 325 children (2 to 7 years) & Weak \\
\hline Helland et al. $(2017)^{26}$ & Norway - Kristiansand/Cross-sectional & $\begin{array}{c}505 \text { children } \\
\text { (mean age of } 2 \text { years) }\end{array}$ & Weak \\
\hline Maiz and Balluerka (2018) ${ }^{15}$ & Spain - San Sebastián/Cross-sectional & 464 children & Moderate \\
\hline Rioux et al. $(2018)^{27}$ & France - Lyon and Paris/Cross-sectional & 109 children ( 3 to 4 years) & Moderate \\
\hline Kähkönen et al. (2018) ${ }^{28}$ & Finland - Helsinki/Cross-sectional & 130 children ( 3 to 5 years) & Moderate \\
\hline Kutbi et al. (2019) 29 & Saudi Arabia - Jeddah/Cross-sectional & 216 children ( 3 to 7 years) & Moderate \\
\hline
\end{tabular}




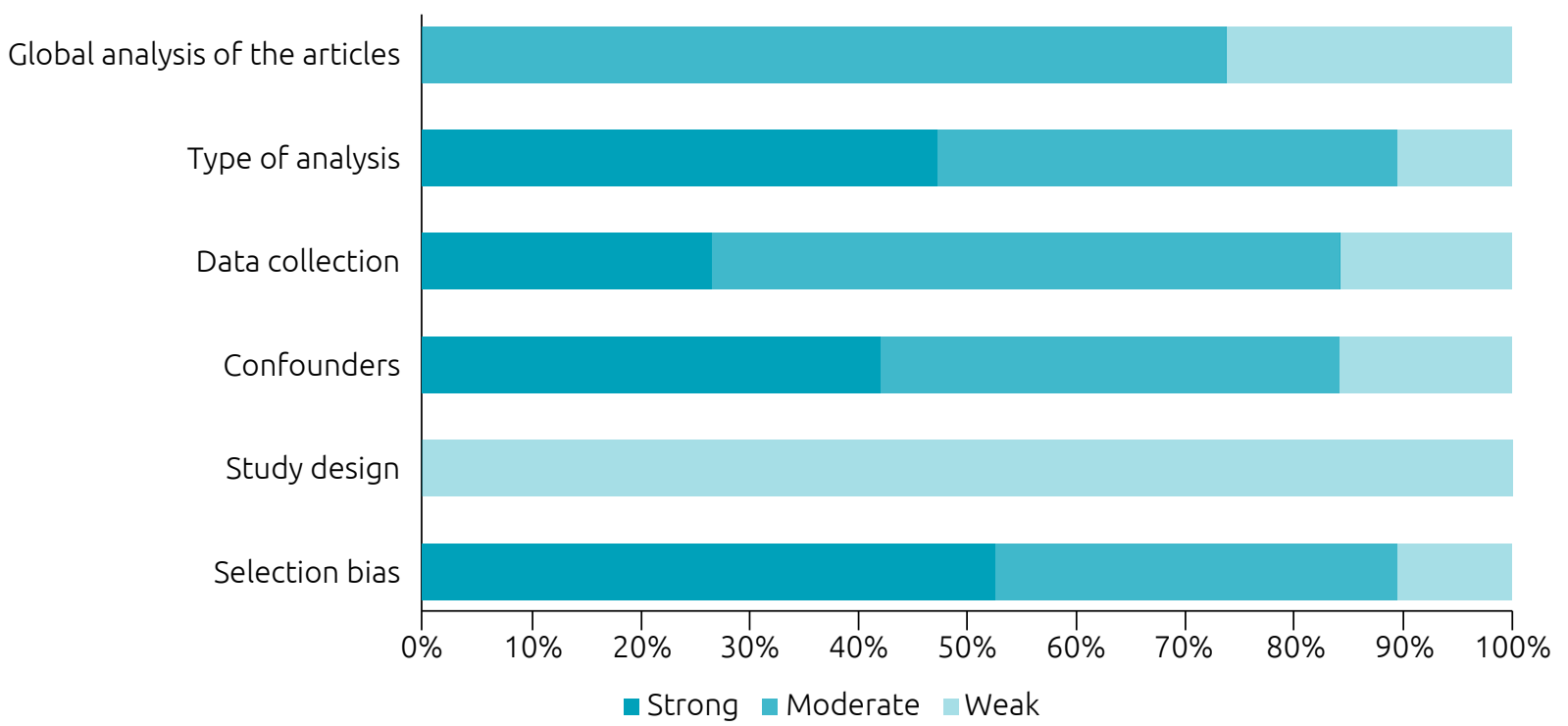

Figure 2 Summarization of the global methodological rigor of studies selected for the systematic review of factors associated with food neophobia in children.

Table 2 Prevalence and level of food neophobia in childhood.

\begin{tabular}{|c|c|c|c|}
\hline Author/year & $\begin{array}{l}\text { Prevalence } \\
(\%)\end{array}$ & Neophobia scale & $\begin{array}{l}\text { Prevailing level } \\
\text { of neophobia }\end{array}$ \\
\hline Falciglia et al. $(2000)^{2}$ & 32.8 & - & - \\
\hline Galloway et al. (2003) & 33 & - & - \\
\hline Cooke et al. $(2006)^{19}$ & 47.7 & Child Food Neophobia Scale - Pliner, 1994 & High \\
\hline Russell and Worsley (2008) ${ }^{16}$ & - & Child Food Neophobia Scale - Pliner and Hobden, 1992 & Moderate \\
\hline Mustonen and Tuorila $(2010)^{20}$ & - & Food Neophobia Scale - Pliner and Hobden, 1992 & Moderate \\
\hline Howard et al. $(2012)^{17}$ & - & Food Neophobia Scale - Pliner and Hobden, 1992 & Moderate \\
\hline Tan and Holub (2012) ${ }^{14}$ & - & Child Food Neophobia Scale - Pliner, 1994 & Moderate \\
\hline Cassells et al. $(2014)^{21}$ & 13 & Food Neophobia Scale - Pliner and Hobden, 1992 & High \\
\hline Laureati et al. $(2014)^{22}$ & - & Food Neophobia Scale - Pliner and Hobden, 1992 & High \\
\hline Maratos and Staples $(2015)^{23}$ & 27.1 & Food Neophobia Scale - Pliner and Hobden, 1992 & High \\
\hline Perry et al. (2015) ${ }^{18}$ & 12.8 & - & - \\
\hline Kaar et al. $(2016)^{13}$ & - & Food Neophobia Scale - Pliner and Hobden, 1992 & Moderate \\
\hline Moding and Stifter $(2016)^{24}$ & - & Child Food Neophobia Scale - Pliner, 1994 & Moderate \\
\hline Koziot-Kozakowska et al. $(2018)^{25}$ & 87.7 & Food Neophobia Scale - Pliner and Hobden, 1992 & Moderate \\
\hline Helland et al. $(2017)^{26}$ & - & Child Food Neophobia Scale - Pliner, 1994 & Moderate \\
\hline Maiz and Balluerka (2018) & 28.7 & $\begin{array}{c}\text { Spanish Child Food Neophobia Scale - Maiz, Balluerka, } \\
\text { and Maganto, } 2016\end{array}$ & High \\
\hline Rioux et al. $(2018)^{27}$ & - & Child Food Neophobia Scale - Pliner, 1994 & Moderate \\
\hline Kähkönen et al. (2018) & 24.5 & - & - \\
\hline Kutbi et al. $(2019)^{29}$ & 100 & Food Neophobia Scale - Pliner and Hobden, 1992 & High \\
\hline
\end{tabular}


The prevalence and level of food neophobia in childhood are highlighted in Table 2. The prevalence of food neophobia was present in $10(53 \%)$ studies and varied between $12.8 \%{ }^{18}$ and $100 \% .{ }^{29}$ To identify neophobia, some scales were used, such as Pliner and Hobden's, ${ }^{13,16,17,20-23,25,29}$ Pliner's ${ }^{14,19,24,26,27}$ or Maiz, Balluerka, and Maganto's. ${ }^{15}$ Based on these instruments, the level of neophobia was estimated, obtaining an average score consistent with the moderate ${ }^{13,14,16,17,20,24-27}$ and high ${ }^{15,19,21-23,29}$ classification for neophobia.

As for factors associated with this condition in children, the following stand out: parental influence on eating habits, ${ }^{17,23}$ children's innate preference for sweet and savory flavors, ${ }^{18,19}$ influence of the sensory aspect of foods, ${ }^{20,23,27,29}$ parents' pressure for the child to eat, ${ }^{13,21,24,29}$ parents' lack of encouragement and/or affection at mealtime, ${ }^{22,24}$ diets with low variety and low nutritional quality, ${ }^{2,12,14,17-19,22,23,26}$ childhood anxiety, ${ }^{12,15}$ little time to prepare the meals, ${ }^{12}$ mothers with food neophobia, ${ }^{12}$ limited availability of variety of foods, ${ }^{14}$ lack of exposure to new foods, ${ }^{16}$ preference for foods rich in fat and/or sugar, ${ }^{16}$ parents' difficulty in interpreting signs of hunger and satiety, ${ }^{21}$ child's lack of autonomy in eating, ${ }^{23}$ negative reactions to new stimuli, ${ }^{24}$ family residing in rural areas, ${ }^{25}$ and low education level of moth$\operatorname{ers}^{28}$ (Table 3).

Table 3 Source environment of the sample and factors associated with food neophobia in children.

\begin{tabular}{|c|c|c|}
\hline Author/year & $\begin{array}{l}\text { Source environment } \\
\text { of the sample }\end{array}$ & Associated factors \\
\hline Falciglia et al $(2000)^{2}$ & School environment & Diet with low variety and quality. \\
\hline Galloway et al. (2003) & Home environment & $\begin{array}{l}\text { Childhood anxiety; } \\
\text { Mothers with food neophobia; } \\
\text { Little time to prepare meals. }\end{array}$ \\
\hline Cooke et al. (2006) ${ }^{19}$ & School environment & $\begin{array}{l}\text { Diet with low variety and quality; } \\
\text { Children's innate preference for sweet and savory flavors. }\end{array}$ \\
\hline Russell and Worsley (2008) ${ }^{16}$ & School environment & $\begin{array}{l}\text { Diet with low variety and quality; } \\
\text { Lack of exposure to new foods; } \\
\text { Preference for fats and/or sugars. }\end{array}$ \\
\hline Mustonen and Tuorila (2010) ${ }^{20}$ & School environment & $\begin{array}{l}\text { Diet with low variety and quality; } \\
\text { Sensory aspect of the food. }\end{array}$ \\
\hline Howard et al. (2012) ${ }^{17}$ & Pediatric outpatient clinic & $\begin{array}{l}\text { Diet with low variety and quality; } \\
\text { Parental influence on eating habits. }\end{array}$ \\
\hline Tan and Holub (2012) $)^{14}$ & Home environment & $\begin{array}{l}\text { Diet with low variety and quality; } \\
\text { Limited availability of variety of foods; } \\
\text { Preference for fats and/or sugars. }\end{array}$ \\
\hline Cassells et al. (2014) ${ }^{21}$ & Pediatric outpatient clinic & $\begin{array}{c}\text { Mothers' food beliefs; } \\
\text { Parents' pressure for children to eat; } \\
\text { Parents' difficulty in interpreting hunger/satiety. }\end{array}$ \\
\hline Laureati et al. (2014) 22 & School environment & $\begin{array}{l}\text { Diet with low variety and quality; } \\
\text { Parents' lack of encouragement }\end{array}$ \\
\hline Maratos and Staples (2015) ${ }^{23}$ & School environment & $\begin{array}{l}\text { Diet with low variety and quality; } \\
\text { Visual aspect of the food. }\end{array}$ \\
\hline Perry et al. (2015) & Pediatric outpatient clinic & $\begin{array}{l}\text { Diet with low variety and quality; } \\
\text { Children's innate preference for sweet and savory flavors. }\end{array}$ \\
\hline Kaar et al. (2016) ${ }^{13}$ & Home environment & $\begin{array}{l}\text { Parental influence on eating habits; } \\
\text { Parents' pressure for children to eat; } \\
\text { Children's lack of autonomy in eating. }\end{array}$ \\
\hline Moding and Stifter (2016) & Hospital environment & $\begin{array}{c}\text { Negative reactions to new stimuli; } \\
\text { Parents' pressure for children to eat; } \\
\text { Parents' lack of encouragement and/or affection }\end{array}$ \\
\hline Kozioł-Kozakowska et al. $(2018)^{25}$ & School environment & $\begin{array}{l}\text { Diet with low variety and quality; } \\
\text { Family residing in rural areas. }\end{array}$ \\
\hline Helland et al. (2017) & School environment & $\begin{array}{l}\text { Diet with low variety; } \\
\text { Sensory aspects of food. }\end{array}$ \\
\hline Maiz and Balluerka (2018)15 & School environment & $\begin{array}{c}\text { Anxiety signs in childhood; } \\
\text { Worse social, physical, and academic self-concept. }\end{array}$ \\
\hline Rioux et al. $(2018)^{27}$ & School environment & $\begin{array}{l}\text { Sensory aspect of the food; } \\
\text { Low inductive reasoning. }\end{array}$ \\
\hline Kähkönen et al. (2018)²8 & School environment & $\begin{array}{l}\text { Diet with low variety and quality; } \\
\text { Mothers' low education level. }\end{array}$ \\
\hline Kutbi et al. (2019) ${ }^{29}$ & School environment & $\begin{array}{l}\text { Parents' pressure for children to eat; } \\
\text { Sensory aspect of the food. }\end{array}$ \\
\hline
\end{tabular}




\section{DISCUSSION}

Food neophobia is a behavior prevalent in childhood because it is a period of tactile, taste-related, and olfactory discoveries and when eating habits are formed. This prevalence is even greater when considering that, sometimes, neophobia is not identified. ${ }^{5}$ The causality that determines it has not yet been fully recognized. This phenomenon is determined by the interaction between several complex factors such as: biological, anthropological, economic, psychological, and/or sociocultural factors, which are shaped by the individual context. ${ }^{8}$

In this review, a high variability in the prevalence of food neophobia in children was observed. Such prevalence is determined by age, and its development is deemed greater from two to five years of age. ${ }^{5,6}$ During puberty and adulthood, the risk of developing this attitude toward food significantly decreases; however, in old age, it increases again, which is explained by the fact that neophobic behavior can protect the organism from possible intoxication due to old age. ${ }^{27}$ Studies performed by Kozioł-Kozakowska et al., ${ }^{25}$ who analyzed the prevalence of food neophobia in the population of Polish preschool children, showed that this attitude is observed in 1 out of 10 children.

Some of the selected studies used the food neophobia scales developed by Pliner and Hobden, ${ }^{13,16,17,20-23,25,29}$ Pliner $^{14,19,24,26,27}$, or by Maiz, Balluerka, and Maganto ${ }^{15}$ to measure the level of this behavior in the sample. This heterogeneity of instruments reinforces the findings of Damsbo-Svendsen,$^{30}$ who pinpointed the diversity of tools used to measure food neophobia due to different strengths and weaknesses, considering that no instrument is sufficiently adequate to measure all involved aspects. The most used scale was that of Pliner and Hobden, composed of 10 items that seek to analyze the willingness to try new foods; however, its limitation is the fact that it does not include foods from different cultures. ${ }^{31}$ In addition, it is a scale formulated for the adult population, which can generate distorted results when applied to children.

Conversely, the Pliner scale is a version of the aforementioned scale, adapted for children aging 5 to 11 years and that comprises 34 foods. Parents report their children's familiarity with these foods and their willingness to try them. ${ }^{1}$ Among its limitations, it does not include foods from different cultures either and is formulated for an age group higher than that found in several studies whose authors have used it. The third scale is aimed at children and adolescents, a Spanish version, culturally adapted from the Food Situation Questionnaire (FSQ), composed of 10 items also seeking to assess the willingness to try new foods. ${ }^{32}$ Taking into account the weaknesses and strengths of the aforementioned instruments, it is paramount to choose the one that best evaluates food neophobia in the target audience, in such a way not to generate inconsistent results.
The average score presented in the articles that used this tool indicated a higher occurrence of the moderate $13,14,16,17,20,24-27$ and high ${ }^{15,19,21-23,29}$ levels of neophobia, which is a worrisome factor, because it demonstrates greater dietary restrictions as well as greater reluctance to new foods. High levels of food neophobia are associated with a lack of variety in food and a high intake of saturated fat, contributing to a diet with low nutritional quality. ${ }^{2}$ Among nutrients commonly restricted when facing this behavior, vitamin E, folate, calcium, zinc, and fibers stood out. ${ }^{2}$ It should be considered that such nutrients are essential for maintaining health, especially in childhood, which is a period of development in which nutritional deficiencies can lead to poor physical and intellectual development, impairment of the nervous and immune system, future occurrence of chronic non-communicable diseases, among other associated morbidities. ${ }^{10}$

Among the associated factors, the parental influence on eating habits stands out. ${ }^{17,23}$ This encompasses several other factors observed in this study, such as mothers who present neophobia to the same foods as their children, ${ }^{12}$ considering that their diets have low consumption of vegetables, an important food group for adequate nutrition and which is the target of neophobic behaviors. ${ }^{12,16}$ Studies corroborate that the mother's high level of neophobia is correlated with the highest neophobia in children. ${ }^{33-36}$ Thus, the importance of parents in having adequate eating habits as a strategy to reduce food neophobia in childhood is reinforced.

The role of parents in forming adequate eating habits in children has been evidenced in the literature. ${ }^{14,16,23,37-39}$ Children's eating behaviors are shaped by observation and imitation of the behavior and reactions of people around them. ${ }^{38}$ Children tend to follow their parents' habits due to the affective bond, which includes taking an interest in the same foods consumed by them. ${ }^{23}$ The study conducted by Harper and Sanders showed that children were much more likely to try an unknown food when, at the same time, their mothers also ate the product and reacted with enthusiasm. This effect was stronger than when the parents just verbally encouraged the child to try the food. ${ }^{39}$ Thus, it is important for parents to be willing to include such foods in their habits, in such a way they arouse the child's interest.

One of the parents' explanation for the low supply of nutritionally rich foods was the rush to eat due to a busy routine, ${ }^{12}$ in such a way that they resort to foods that are easy to prepare and that are mostly of low nutritional value, in addition to being rich in sodium and fats. Furthermore, it is important to include the child when preparing the food. The analysis performed by van der Horst ${ }^{40}$ showed that the involvement of children in the preparation of meals can reduce the intensity of neophobic behaviors and contribute to the construction of 
positive experiences with food. Thus, the importance of availability, accessibility to varied and high-nutritional value foods, and the inclusion of children in the preparation of meals in the family environment is noteworthy.

In this environment, not only exposure to these foods is important, but also the way they are offered, considering that a factor strongly associated with food neophobia is the parent's pressure for children to eat ${ }^{13,21,24,29}$ and the parents' lack of encouragement and/or affection at mealtime. ${ }^{22,24}$ This pressure often results from the parents' difficulty in interpreting the signs of hunger and satiety, associated with concerns about the low weight of their children. ${ }^{21}$ In addition, the absence of affective behavior during meals contributes to children associating this moment with displeasure, with a mere physiological need. Thus, the importance of establishing a good relationship between the child and the food is disregarded. This relationship will contribute to arouse interest in the flavors, textures, and sensations of the food. These are emotional aspects that have a great influence on the emergence of neophobic behaviors. Therefore, the environment during mealtime must promote the pleasure in eating.

Parents' pressure for children to eat foods they do not like results in greater resistance to their consumption. Studies have confirmed that the more authoritative the parents are during the mealtime, the more often the child rejects the offered foods. ${ }^{17,35,41}$ This corroborates the conclusions of Rigal et al. ${ }^{42}$, who found it difficult to feed children aged 20 to 36 months mainly as a result of authoritarian coercive practices on the part of their parents, who force the child to consume the rejected foods. Interestingly, the authors also pointed out that a permissive feeding style, in which the parents satisfy all the child's wishes to avoid food conflicts, does not increase the child's willingness to try unknown food. Thus, parents must assess their child's subjectivities and choose the best path to succeed in introducing food.

The innate predilection for sweet and savory flavors and the aversion to bitter and acidic substances consisted in one of the factors associated with food neophobia. There is a low level of acceptance on the part of children for new food products whose predominant taste is bitterness or acidity. Such behavior may potentially contribute to shaping the neophobic behavior toward specific types of food, especially those with a distinctly bitter taste. ${ }^{34,43,44}$ Many analyses have shown that vegetables consist in the most frequently rejected food group due to hypersensitivity to bitter taste. ${ }^{37,44-46}$ Hence, the importance of introducing different flavors in the child's diet stands out, in order to shape future food preferences.

Likewise, breastfeeding becomes extremely important, considering that during the consumption of breast milk the child has the possibility to taste many flavors, depending on the type of food chosen by the mother. This contributes to the greater acceptance of new foods when introducing foods to children, mainly foods that the mother regularly consumed during pregnancy and lactation. ${ }^{47}$ Children fed with milk formula tend to get used to the constant and specific taste of the mixture and, consequently, show less tolerance or even aversion during exposure to new foods. ${ }^{37,43,44,48}$ A study performed by Mennella et al. ${ }^{49}$ found that children whose mothers consumed carrot juice in the third trimester of pregnancy and/or during breastfeeding were more likely to eat carrot puree when compared with children whose mothers did not drink the juice. Such information highlights the importance of healthier food choices since pregnancy and lactation, in order to minimize neophobic behavior in childhood.

The child's resistance to eat certain foods can also be conditioned by the late introduction of new products in the diet. The openness to taste unknown flavors is greater in babies aging up to 12 months and decreases with age. ${ }^{37}$ In addition, the continuous exposure of a new food after the child's initial negative reaction may result in the need to eliminate that food from the daily diet. ${ }^{47}$ Researchers have shown that only 10 to 15 positive experiences are sufficient to result in the food product acceptance. ${ }^{38,47,48}$ Furthermore, the sensory perception of new foods, with varying appearance, consistency, and texture, can weaken the children's reluctance to eat them later in life. ${ }^{47,50}$ Another common mistake in the introduction of food is the imposition of the parents' food preferences, preventing children from knowing different foods and exercising their own food choices. ${ }^{51}$ These findings reinforce the importance of the necessary care in the child's food introduction in order to reduce food neophobia.

Diets with low variety and low nutritional quality $2,12,14,17-19,22,23,26$ are characteristics strongly associated with food neophobia, since this behavior does not often restrict the amount of ingested food, but commonly affects the feeding quality. Children with this behavior have a restricted diet, mainly regarding nutrients required for the maintenance of health, which causes severe nutritional deficiencies and, consequently, contributes to the emergence of morbidities.

The low variety and nutritional quality affect several food groups, mainly vegetables, meats, and fruits, ${ }^{16}$ foods rich in nutrients and important allies for an adequate diet. Another factor that contributes to an unbalanced diet is the fact that neophobic behaviors to these foods are commonly associated with high consumption of fats and sugars. ${ }^{2,16}$ In addition, the children's innate preference for sweet and savory flavors means that these foods are not the target of neophobia. ${ }^{18.19}$ 
Restricted diets are mainly linked to parental influence, considering that parents and other people in the child's environment usually offer only what is part of the family's eating habits and their food beliefs. ${ }^{21}$ Such conduct deprives children of trying new foods, often not giving them the necessary autonomy in their feeding. ${ }^{13}$ Thus, it is necessary for food to be available to children even if they are not part of the family's eating habits, in such a way to stimulate their autonomy in choosing their food.

Another factor that affects the attitude toward food is childhood anxiety. Anxiety ${ }^{12,15}$ is a common emotional disorder in neophobic children, and is associated with the fact that the parents of these children are not used to encouraging them to actively participate in their meal, ${ }^{13}$ such as in choosing the food and preparing the meal, in addition to the frequent pressure to eat exerted by the parents. ${ }^{13,21,24,29}$ It has been demonstrated that when children are forced to eat foods they do not want to, they start feeling anxious and tense, and their distaste for the foods increases.

This contributes to the development of negative associations related to the consumption of meals, and leads to the exacerbation of neophobic behaviors. ${ }^{37,41,52}$ It was also noted that these children have difficulties in socializing in the school environment, which affects their social, physical, and academic self-concept. ${ }^{15}$ Therefore, making the moment of eating pleasurable, with affective behaviors, and inducing the child's participation in the meals can minimize the occurrence of anxiety signs, considering that they consist in alternatives that provide safety and autonomy to the child.

Moreover, a positive correlation was found between food neophobia and negative reactions to new stimuli, ${ }^{24,27}$ even when they were not food stimuli. Children who had a higher level of neophobia feared novelties, thus avoiding objects and foods with unknown shapes, colors, or textures. Conducting studies for analyzing the presence of anxiety before and after the occurrence of food neophobia would be relevant to enable a better characterization of the association of anxiety with food neophobia in children.

The place of residence was also a factor associated with neophobic behavior in childhood. Children living in urban areas had a lower level of food neophobia compared with those living in rural areas. ${ }^{25}$ This characteristic may be related to the availability of food in these places, since the access to variety is usually difficult in rural areas ${ }^{53}$. Therefore, it must be considered that exposure and availability to new foods are essential aspects to avoid or intervene in food neophobia.

Another factor related to food neophobia in childhood was the parents' low level of education..$^{28}$ This relation is explained by the parents' insufficient knowledge to distinguish which food is adequate for their children with regard to: nutritional composition, handling, preparation, and appropriate exposure to food throughout life. Considering that this knowledge plays an important role in attenuating the neophobic behavior, ${ }^{16}$ the parents' low level of education may contribute to the greater supply of food of low nutritional quality and the lower supply of those with rich nutritional value, which may result in the display of neophobic behaviors to these foods. ${ }^{28}$ Thus, the importance of food and nutrition education to parents is highlighted, in order to inform them about adequate food for children as well as to help them identifying, avoiding, or intervening in food neophobia.

Food and nutrition education becomes an essential tool for enabling an active, playful, and interactive process, with encouragement of previous experiences to facilitate the voluntary adoption of eating habits or any behavior related to food that leads to health and welfare. ${ }^{54}$ Furthermore, its advantages are the easy application and low cost, since this practice can be developed individually or in the school environment, for example. There is also sensory-based food education, which has been promising in the intervention of neophobic responses. ${ }^{27}$ This type of activity stimulates curiosity about new shapes, colors, and textures and can contribute to the emotional support and encouragement required to the care of children with neophobic behaviors, when developed in a conducive and comforting environment.

In this sense, the early identification of food neophobia allows for adequate intervention, preventing further damages to the child's health, considering that this long-term behavior can affect the physical, cognitive, and psychosocial development. ${ }^{5,7,10}$ The interprofessional approach is paramount in this process due to the complexity that permeates this condition. It is believed that interprofessional care, ${ }^{55}$ through interaction between different knowledge and professional practices, enables a collective conduct aiming at promoting healthy eating habits. From this perspective, the nutritional follow-up becomes essential to prevent, mitigate, or eradicate food neophobia, and this assistance is not only aimed at the child, but also at the family, considering that the family environment is one of the greatest influences in the occurrence of this behavior. ${ }^{5}$ Therefore, a care network is encouraged, in such a way to promote healthy, happy, creative, fun, affective, and pleasurable feeding habits and focused on the child's healthcare needs.

It is noteworthy that this review and the studies included in it have certain limitations, such as the scarcity of Brazilian studies and samples from different sources, in addition to the great variability of scales to measure food neophobia, which makes data comparability impossible. This lack of standardization may have been responsible for the wide variation in the prevalence of food neophobia. Hence, an individualized 
perspective of each research is interesting, taking into account that the lack of uniformity of the neophobia scales can cause generalizations and misinterpretations.

In conclusion, food neophobia significantly determines the children's eating habits. The prevalence found in the selected studies confirms that it is a behavior easily displayed in childhood, especially at higher levels, which are related to severe dietary restrictions and impacts on health. Factors associated with food neophobia mainly referred to the parental influence on eating habits. However, these factors comprised several areas of the child's life, demonstrating the importance of interprofessional follow-up throughout the intervention process.

Accordingly, adopting practices related to food and nutrition education should also be encouraged to enable the deepening of the knowledge of human feeding habits, especially in childhood. Thus, based on the information found in this study, there is need to offer a varied diet, also including foods that are not part of the family eating habits. In order to avoid or intervene in food neophobia, it is necessary to give children autonomy in their feeding habits, to emotionally support them, in addition to motivating them to participate in the preparation of meals, making the moment pleasant and affectionate.

\section{Funding}

This study did not receive any funding.

\section{Conflict of interests}

The authors declare there is no conflict of interests.

\section{REFERENCES}

1. Pliner P. Development of measures of food neophobia in children. Appetite. 1994;23:147-63. https://doi.org/10.1006/ appe.1994.1043

2. Falciglia GA, Couch SC, Gribble LS, Pabst SM, Frank R. Food neophobia in childhood affects dietary variety. J Am Diet Assoc. 2000;100:1474-81. https://doi.org/10.1016/s00028223(00)00412-0

3. Knaapila A, Tuorila H, Silventoinen K, Keskitalo K, Kallela M, Wessman M, et al. Food Neophobia shows heritable variation in humans. Physiol Behav. 2007;91:573-8. https:// doi.org/10.1016/j.physbeh.2007.03.019

4. Viveiros CC. Estudo do comportamento alimentar, preferências alimentares e neofobia alimentar em crianças pré-escolares e da eficácia de um programa de promoção de comportamentos alimentares saudáveis em contexto escolar: um estudo exploratório [master's thesis]. Lisboa: Universidade de Lisboa; 2012.

5. Gaiga CA. Neofobia alimentar e desenvolvimento infantil [undergraduate thesis]. Limeira (SP): Universidade Estadual de Campinas; 2014.

6. Addessi E, Galloway AT, Visalberghi E, Birch LL. Specific social influences on the acceptance of novel foods in 2-5-year-old children. Appetite. 2005;45:264-71. https:// doi.org/10.1016/j.appet.2005.07.007

7. Faccin R. Preferências alimentares e neofobia alimentar em crianças de escolas municipais no município de Porto Alegre [undergraduate thesis]. Porto Alegre (RS): Universidade Federal do Rio Grande do Sul; 2013.

8. Gedrich K. Determinants of nutritional behaviour: a multitude of levers for successful intervention? Appetite. 2003;41:231-8. https://doi.org/10.1016/j. appet.2003.08.005
9. Ramalho C, Sampaio M, Rocha N, Poínhos R. Food neophobia among primary school children and their caregivers. Acta Port Nutr. 2016;7:10-3. http://dx.doi.org/10.21011/apn.2016.0703

10. Medeiros RT. Caracterização da neofobia alimentar em crianças de três a seis anos [master'sthesis]. Natal (RN): Universidade Federal do Rio Grande do Norte; 2008.

11. Moher D, Liberati A, Tetzlaff J, Altman DG. The PRISMA Group. Preferred reporting items for systematic reviews and meta-analyses: the PRISMA statement. PLoS Medicine. 2009;6:e1000097. https://doi.org/10.1371/journal. pmed.1000097

12. Galloway AT, Lee Y, Birch LL. Predictors and consequences of food neophobia and pickiness in young girls. J Am Diet Assoc. 2003;103:692-8. https://doi.org/10.1053/jada.2003.50134

13. Kaar JL, Shapiro AL, Feel DM, Johnson SL. Parental feeding practices, food neophobia, and child food preferences: what combination of factor results in children eating a variety of foods? Food Qual Prefer. 2016;50:57-64. https://doi. org/10.1016/j.foodqual.2016.01.006

14. Tan CC, Holub SC. Maternal feeding practices associated with food neophobia. Appetite. 2012;59:483-7. https://doi. org/10.1016/j.appet.2012.06.012

15. Maiz E, Balluerka N. Trait anxiety and self-concept among children and adolescents with food neophobia. Food Res Int. 2018;105:1054-9. https://doi.org/10.1016/j. foodres.2017.12.037

16. Russell CG, Worsley A. A population-based study of preschoolers' food neophobia and its associations with food preferences. J Nutr Educ Behav. 2008;40:11-9. https:// doi.org/10.1016/j.jneb.2007.03.007

17. Howard AJ, Mallan KM, Byrne R, Margarey A, Daniels LA. Toddlers food preferences. The impact of novel food exposure, maternal preferences and food neophobia. Appetite. 2012;59:818-25. https://doi.org/10.1016/j.appet.2012.08.022 
18. Perry RA, Mallan KM, Koo J, Mauch CE, Daniels LA, Margarey AM. Food neophobia and its association with diet quality and weight in children aged 24 months: a cross sectional study. Int J Behav Nutr Phys Act. 2015;12:13. https://doi. org/10.1186/s12966-015-0184-6

19. Cooke L, Carnell S, Wardle J. Food neophobia and mealtime food consumption in 4-5 year old children. Int J Behav Nutr Phys Act. 2006;3:14. https://doi.org/10.1186/1479-5868-3-14

20. Mustonen S, Tuorila H. Sensory education decreases food neophobia score and encourages trying unfamiliar foods in 8-12-year-old children. Food Qual Prefer. 2010;21:353-60. https://doi.org/10.1016/j.foodqual.2009.09.001

21. Cassells EL, Margarey AM, Daniels LA, Mallan KM. The influence of maternal infant feeding practices and beliefs on the expression of food neophobia in toddlers. Appetite. 2014;82:36-42. https://doi.org/10.1016/j.appet.2014.07.001

22. Laureati M, Bergamaschi V, Pagliarini E. School-based intervention with children. Peer-modeling, reward and repeated exposure reduce food neophobia and increase liking of fruits and vegetables. Appetite. 2014;83:26-32. https://doi.org/10.1016/j.appet.2014.07.031

23. Maratos FA, Staples P. Attentional biases towards familiar and unfamiliar foods in children. The role of food neophobia. Appetite. 2015;91:220-5. https://doi.org/10.1016/j. appet.2015.04.003

24. Moding KJ, Stifter CA. Temperamental approach/withdrawal and food neophobia in early childhood: concurrent and longitudinal associations. Appetite. 2016;107:654-62. https://doi.org/10.1016/j.appet.2016.09.013

25. Kozioł-Kozakowska A, Piórecka B, Schlegel-Zawadzka M. Prevalence of food neophobia in pre-school children from Southern Poland and its association with eating habits, dietary intake and anthropometric parameters: a cross-sectional study. Public Health Nutr. 2018;21:1106-14. https://doi. org/10.1017/s1368980017003615

26. Helland SH, Bere E, Bjørnarå HB, Øverby NC. Food neophobia and its association with intake of fish and other selected foods in a Norwegian sample of toddlers: a cross-sectional study. Appetite. 2017;114:110-7. https://doi.org/10.1016/j. appet.2017.03.025

27. Rioux C, Leglaye L, Lafraire J. Inductive reasoning, food neophobia, and domain-specificity in preschoolers. Cogn Dev. 2018;47:124-32. https://doi.org/10.1016/j. cogdev.2018.05.001

28. Kähkönen K, Rönkä A, Hujo M, Lyytikäinen A, Nuutinen O. Sensory-based food education in early childhood education and care, willingness to choose and eat fruit and vegetables, and the moderating role of maternal education and food neophobia. Public Health Nutr. 2018;21:2443-53. https:// doi.org/10.1017/s1368980018001106

29. Kutbi HA, AlhatmiAA, Alsolami MH, Alghamdi SS, Albaggar SM, Mumena WA, et al. Food neophobia and pickiness among children and associations with socioenvironmental and cognitive factors. Appetite. 2019;142:1043-73. https:// doi.org/10.1016/j.appet.2019.104373

30. Damsbo-Svendsen M, Frøst MB, Olsen A. A review of instruments developed to measure food neophobia. Appetite. 2017;113:358-67. https://doi.org/10.1016/j. appet.2017.02.032
31. Pliner $P$, Hobden KL. Development of a scale to measure the trait of food neophobia in humans. Appetite. 1992;19:10520. https://doi.org/10.1016/0195-6663(92)90014-W

32. MaizE, Balluerka N, Maganto C. Validation of a questionnaire to measure the willingness to try new foods in Spanish-speaking children and adolescents. Food Qual Prefer. 2016;48:13845. https://doi.org/10.1016/j.foodqual.2015.09.004

33. Dematté ML, Endrizzi I, Gasperi F. Food neophobia and its relations with oflaction. Front Psychol. 2014;5:127. https:// doi.org/10.3389/fpsyg.2014.00127

34. Kozioł-Kozakowska A, Piórecka B, Pediatrii K, Gastroenterologii I, Żywienia P, Pediatrii I, et al. Neofobia żywieniowa, jej uwarunkowania i konsekwencje zdrowotne. Stand Med Pediatr. 2013;1:1-6.

35. Kral TV, Rauh EM. Eating behaviors of children in the context of the ir family environment. Physiol Behav. 2010;100:56773. https://doi.org/10.1016/j.physbeh.2010.04.031

36. Faith MS, Heo M, Keller KL, Pietrobelli A. Child food neophobia is heritable, associated with less compliant eating, and moderates familial resemblance for BMI. Obesity (Silver Spring). 2013;21:1650-5. https://doi.org/10.1002/oby.20369

37. Lafraire J, Rioux C, Giboreau A, Picard D. Food rejections in children: cognitive and social/environmental factors involved in food neophobia and picky/fussy eating behavior. Appetite. 2016;96:347-57. https://doi.org/10.1016/j.appet.2015.09.008

38. Cosmi V, Scaglioni S, Agostoni C. Early taste experiences and later food choices. Nutrients. 2017;9:107. https://doi. org/10.3390/nu9020107

39. Harper LV, Sanders KM. The effects of adults' eating on young children's acceptance of unfamiliar foods. J Exp Child Psychology. 1975;20:206-14.

40. van der Horst L. Over coming picky eating. Eating enjoyment as a central aspect of children's eating behaviors. Appetite. 2012;58:567-74. https://doi.org/10.1016/j. appet.2011.12.019

41. Mitchell GL, Farrow C, Haycraft E, Meyer C. Parental influences on children's eating behaviour and characteristics of successful parent-focussed interventions. Appetite. 2013;60:85-94. https://doi.org/10.1016/j. appet.2012.09.014

42. Rigal N, Chabanet C, Issanchou S, Monnery-Patris S. Links between maternal feeding practices and children's eating difficulties. Validation of French tools. Appetite. 2012;58:62937. https://doi.org/10.1016/j.appet.2011.12.016

43. Blissett J, Fogel A. Intrinsic and extrinsic influences on children's acceptance of new foods. Physiol Behav. 2013;121:89-95. https://doi.org/10.1016/j.physbeh.2013.02.013

44. Scaglioni S, De Cosmi V, Ciappolino V, Parazzini F, Brambilla P, Agostini C. Factors influencing children's eating behaviours. Nutrients. 2018;10:706. https://doi.org/10.3390/nu10060706

45. Dovey TM, Staples PA, Gibson EL, Halford JC. Food neophobia and 'picky/ fussy' eating in children: a review. Appetite. 2008;50:181-93. https://doi.org/10.1016/j.appet.2007.09.009

46. Dinehart ME, Hayes JE, Bartoshuk LM, Lanier SL, Duffy VB. Bittertastemarkers explain variability in vegetables sweetness, bitterness, and intake. Physiol Behav. 2006;87:30413. https://doi.org/10.1016/j.physbeh.2005.10.018 
47. Lobos P, Januszewicz A. Food neophobia in children. Pediatr Endocrinol Diabetes Metab. 2019;25:150-4. https://doi. org/10.5114/pedm.2019.87711

48. Cooke L. Genetic and environmental influences on food neophobia. In: Reilly S, editor. Woodhead publishing series in foodscience, technology and nutrition. Food neophobia: behavioral and biological influences. Cambridge: Woodhead Publishing; 2018. p.237-54.

49. Mennella JA, Jagnow CP, Beauchamp GK. Prenatal and postnatal flavor learning by human infants. Pediatrics. 2001;107:E88. https://doi.org/10.1542/peds.107.6.e88

50. Coulthard H, Sealy AM. Play with your food! Sensory play is associated with tasting of fruits and vegetables in preschool children. Appetite. 2017;113:84-90. https://doi.org/10.1016/j. appet.2017.02.003

51. Carruth BR, Skinner JD. Revisiting the pick yeater phenomenon: neophobic behaviors of young children. J Am Coll Nutr. 2000;19:771-80. https://doi.org/10.1080/0 7315724.2000 .10718077
52. Mosli RH, Miller AL, Peterson KE, Lumeng JC. Sibling feeding behavior: mothers as role models during mealtimes. Appetite. 2016;96:617-20. https://doi.org/10.1016/j. appet.2015.11.006

53. Flight I, Leppard P, Cox DN. Food neophobia and associations with cultural diversity and socio-economic status amongst rural and urban Australian adolescents. Appetite. 2003;41:51-9. https://doi.org/10.1016/s01956663(03)00039-4

54. Carmo MC, Castro LC, Novaes JF. Educação nutricional para pré-escolares: uma ferramenta de intervenção. 2013;12:6474. https://doi.org/10.5007/1807-0221.2014v11n18p63

55. Mattos MP, Gomes DR. Vivências interprofissionais em saúde: formação inovadora da Liga Interdisciplinar de Saúde da Criança no Oeste da Bahia. In: Ferla AA, Torres OM, Baptista GC, Schweickardt JC, editors. Ensino cooperativo e aprendizagem baseada no trabalho: das intenções à ação em equipes de saúde. Porto Alegre (RS): Rede Unida; 2019. p.26-45. 